\title{
The combination of Demodex folliculorum and Aerobic Bacteria in the Etiopathogenesis of Chronic Blepharitis
}

\section{Kronik Blefarit Etyopatogenezinde Demodex folliculorum ve Aerop Bakterilerin Birlikteliği}

\author{
Murat Cakmakliogullari', @Ahmet Ozbilgin² \\ 'Karabük University Training and Research Hospital Ophthalmology Department, Karabük, Turkey \\ ${ }^{2}$ Celal Bayar University School of Medicine Medical Parasitology Department, Manisa, Turkey
}

\begin{abstract}
Aim: This study was conducted to investigate the presence of thecombination of Demodex folliculorum and aerobic bacteria in patients with chronic blepharitis.

Material and Method: Seventy-one patients diagnosed with chronic blepharitis were evaluated for the presence of $D$. folliculorum by light microscope examination of samples prepared from eyelashes collected by eyelash epilation. Culture samples were also obtained from patients' eyelid margins. Bacterial strainsamong the predominant bacterial colonies grown in cultures were identified using the BD Phoenix identification system (BD Diagnostic Systems, Sparks, USA). Patients were divided into two groups, Demodex-positive and Demodex-negative,and compared according to bacterial production and bacterial strains produced.

Results: D. folliculorum was identified in 42 (59.1\%) patients. Comparison between Demodex-positive and -negative groups revealeda statistically significant increase in Demodex positivity with age. There was no significant relationship between gender and Demodex positivity. The Demodex-positive group showed a statistically significantly higher bacterial growth in the culture samples than the Demodex-negative group. Both groups exhibited a predominance of Staphylococcus epidermidis. S. epidermidis (38.1\% vs. $31.0 \%)$, Staphylococcus aureus (19.0\% vs. $10.3 \%)$, and Corynebacterium spp. (16.7\% vs. $6.9 \%)$ were detected at higher rates in the Demodex-positive group than in the Demodexnegative group. There was no statistically significant difference between both groups regarding the presence of these bacterial species.
\end{abstract}

Conclusions: Patients with chronic blepharitis could have a mixedinfection site with the combination of $D$. folliculorum and aerobic bacteria found in the normal eyelid flora.

Keywords: Chronic blepharitis, Demodex folliculorum, aerobic bacteria, etiopathogenesis
Öz

Amaç: Bu çalışmada kronik blefarit tanısı almış hastalarda $D$. folliculorum ile aerop bakteri birlikteliğini araştırmayı amaçladık.

Gereç ve Yöntem: Kronik blefarit tanısı alan 71 hastada, kirpik epilasyonu ile alınan kirpiklerden hazırlanan preparatlar ışı mikroskobunda $D$. folliculorum varlığı açısından değerlendirildi. Aynı zamanda bu hastaların kapak marjından kültür örnekleri alındı. Kültürde üreyen baskın bakteri kolonilerinin tür tayinleri, BD Phoenix (BD Diagnostic Systems, Sparks, USA) tanımlama sistemi kullanılarak yapıldı. Hastalar, D. folliculorum saptananlar Demodex pozitif saptanmayanlar ise Demodex negatif olmak üzere iki gruba ayrıldı. Gruplar bakteri üremesi ve üreyen bakteri türlerine göre karşılaştırıldı.

Bulgular: Hastaların 42'sinde $(\% 59,1)$ D. folliculorum varlığı saptandı. Demodex pozitif grupla Demodex negatif grup karşılaştııılığında yaş arttıkça Demodex pozitifliğinin de istatistiksel olarak arttığı saptandı. Cinsiyet ile Demodex pozitifliği arasında anlamlı bir ilişki bulunmadı. Demodex pozitif grupta alınan kültür örneklerinde bakteri üremesi Demodex negatif gruba göre anlamlı yüksek bulundu. Her iki grupta en sık S. epidermidis üremesi olduğu saptandı. Demodex pozitif hastalarda Demodex negatif olanlara göre daha yüksek oranda görülen bakteri türlerinin S. epidermidis $(\% 38,1 ; \% 31,0)$, S. aureus (\%19,0;\%10,3) ve Corinobacterium spp. $(\% 16,7 ; \% 6,9)$ olduğu saptand. Demodex pozitif ve Demodex negatif gruplarda üreyen bakteri türleri karşılaştırıldığında türler arasında anlamlı bir fark bulunmadı.

Sonuç: Kronik blefaritli hastalarda sıklıkla D. folliculorum ile normal kapak florasında bulunan aerop bakterilerin birlikte mix enfeksiyon alanı oluşturabileceği düşüncesindeyiz.

Anahtar Kelimeler: Kronik blefarit, D. folliculorum, aerop bakteriler, etyopatogenez

Corresponding (Illetişim): Murat Cakmakliogullari, Karabük University Training and Research Hospital Ophthalmology Department, Karabük, Turkey

E-mail (E-posta): drmurat3545@gmail.com

Received (Geliş Tarihi): 07.09.2020 Accepted (Kabul Tarihi): 17.12.2020 


\section{INTRODUCTION}

Demodex folliculorum and D. brevis are two strains of Demodex mites found in humans. They are most commonly found as ectoparasites on the human skin and are also present in the eyelid flora. ${ }^{[1]}$ The majority of $D$. folliculorum species are located in the infundibular section of hair follicles, whereas $D$. brevis are located more deeply in the sebaceous gland and ductus. ${ }^{[2]}$

These mites can cause ocular disorders like blepharitis, conjunctivitis and keratitis. ${ }^{[3-5]}$ Blepharitis is a frequently observed clinical condition, generally accompanied by a chronic course. Symptoms primarily include itching, burning, redness, feeling of a foreign body in the eye, and flaking at the eyelash roots. It is generally diagnosed from the clinical appearance of the eyelid and the accompanying symptoms. ${ }^{[6]}$ Mites cause reactive hyperkeratinisation and epithelial hyperplasia by obstructing the sebaceous gland outlets and eyelash root follicles and play a role as a mechanical vector for the spread of bacteria. ${ }^{[7]}$

The most common aerobic bacterial agents causing blepharitis are Staphylococcus epidermidis, S. aureus, and Corynebacterium spp., and the most common parasitic agent is D. folliculorum. ${ }^{[8]}$ This widespread parasite is accepted as a saprophytic organism on the skin, and it is currently accepted as the pathogenic agent of chronic blepharitis; hence, when the parasite is determined, antiparasitic treatment is recommended. ${ }^{[9]}$

We conducted this study to investigate the presence of the combination of $D$. folliculorum and aerobic bacteria in patients diagnosed with chronic blepharitis.

\section{MATERIAL AND METHOD}

\section{Patients}

This study included 71 patients who presented at the Ophthalmology Polyclinic of Karabük University Training and Research Hospital between September 2016 and June 2017 and were diagnosed with chronic blepharitis. Patients were excluded if they had previously undergone eyelid surgery, had a structural disorder of the eyelid, or were using topical or systemic antibiotic treatment. The presence of $D$. folliculorum was determined in the eyelashes obtained by eyelash epilation from patients with chronic blepharitis. The patients were divided into two groups, i.e., those determined as positive and those found as negative for the presence of $D$. folliculorum. Both groups were compared in terms of bacterial production in the culture samples collected from the eyelash margins and the bacterial strains produced.

This study was approved by the Clinical Research Ethics Committee of Karabük University Medical Faculty (no: 13, dated:31/08/2016).

\section{Bacterial Culture and Identification}

Culture samples were obtained from the upper and lower eyelidsusing a sterile swab dampened with sterile saline and were sent to the microbiology laboratory in transport media. The swab samples were inoculated onto $5 \%$ sheepblood agar
(Becton Dickinson, USA), eosin methylene blue agar (Becton Dickinson, USA), and chocolate agar (Becton Dickinson, USA) and then incubated at $35^{\circ} \mathrm{C}$ for $24-48 \mathrm{~h}$. The strains found among the predominant bacterial colonies grown in the culture media were identified using a fully automated BD Phoenix bacterial identification system (BD Diagnostic Systems, Sparks, USA).

\section{Demodex Examination}

Under biomicroscopy, six eyelashes were collected from the upper and lower eyelids of the patients by epilation. The eyelashes were sent to the microbiology laboratory in a sterile petri dish. The eyelash sampleswere mounted on slides and prepared using saline according to the procedure described by English et al. ${ }^{[10]}$ after which they were evaluated under a light microscope at $10 \times$ and $40 \times$ magnification to detect the presence of $D$. folliculorum.

\section{Statistical Analysis}

Statistical analyses were performed using the IBM SPSS version 24.0 software (IBM Corporation, Armonk, NY, USA). Continuous variables were represented as mean \pm standard deviation, and categorical data were represented as number (n) and percentage (\%). In the analyses between groups of continuous variables, conformity of the data to normal distribution was assessed using the Kolmogorov-Smirnov test. Comparisons of two groups of data with normal distribution were conducted using the t-test.The chi-square test was applied for comparisons of categorical data. A value of $p<0.05$ was accepted as statistically significant.

\section{RESULTS}

Among the 71 patients diagnosed with chronic blepharitis, D. folliculorum was detected in 42 (59.1\%) patients. An adult $D$. folliculorum detected in the eyelash sample is shown in Figure 1. The mean age of Demodex-negative patients was $52.34 \pm 10.65$ years (range, 32-72 years), and that of Demodexpositive patient was $63.52 \pm 10.88$ years (range, 35-83 years). There was a statistically significant increase in Demodex positivity with an increase in age $(p<0.001)$. However, there was no statistically significant difference between the groups with respect of gender ( $p>0.05$ ) (Table 1).

\begin{tabular}{|c|c|c|c|c|c|c|c|}
\hline & \multicolumn{2}{|c|}{$\begin{array}{c}\text { Demodex- } \\
\text { Negative }(n=29)\end{array}$} & \multicolumn{2}{|c|}{$\begin{array}{c}\text { Demodex- } \\
\text { Positive }(n=42)\end{array}$} & \multicolumn{2}{|c|}{$\begin{array}{c}\text { Total } \\
(n=71)\end{array}$} & \multirow[t]{2}{*}{$\mathbf{p}$} \\
\hline & $n$ & $\%$ & $\mathbf{n}$ & $\%$ & $n$ & $\%$ & \\
\hline \multicolumn{8}{|c|}{ Age (years) } \\
\hline $30-39$ & 3 & 10.3 & 1 & 2.4 & 4 & 5.6 & \multirow{5}{*}{$<0.001^{*}$} \\
\hline $40-49$ & 10 & 34.5 & 4 & 9.5 & 14 & 19.7 & \\
\hline $50-59$ & 9 & 31.0 & 10 & 23.8 & 19 & 26.8 & \\
\hline $60-69$ & 6 & 20.7 & 16 & 38.1 & 22 & 31.0 & \\
\hline $70+$ & 1 & 3.4 & 11 & 26.2 & 12 & 16.9 & \\
\hline \multicolumn{8}{|l|}{ Gender } \\
\hline Female & 16 & 55.2 & 22 & 52.4 & 38 & 53.5 & \multirow{2}{*}{$0.817^{* *}$} \\
\hline Male & 13 & 44.8 & 20 & 47.6 & 33 & 46.5 & \\
\hline
\end{tabular}



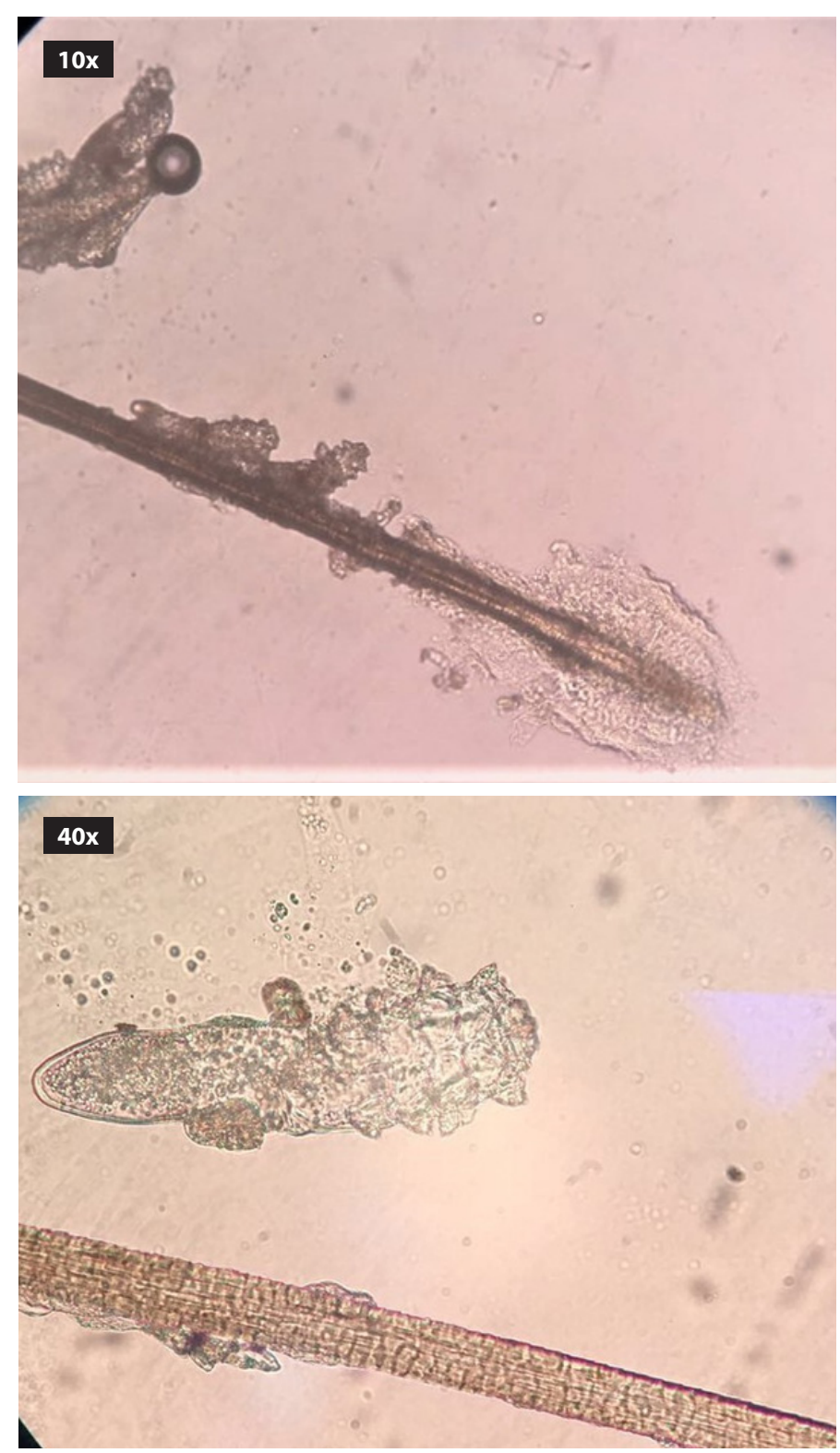

Figure 1. Microscopic eyelash examination of $D$. folliculorum at $10 \times$ and $40 \times$

Regarding bacterial growth, $90.5 \%$ of patients in the Demodexpositive group and $72.4 \%$ of those in the Demodex-negative group had bacterial growth in the cultures. The difference between the two groups with respect to bacterial growth was statistically significant $(p=0.048)$ (Table 2$)$.

Table 2. Comparisons between Demodex-positive and -negative patients with respect to bacterial growth

\begin{tabular}{|c|c|c|c|c|c|c|c|}
\hline & \multicolumn{2}{|c|}{$\begin{array}{c}\text { Demodex- } \\
\text { Negative }(n=29)\end{array}$} & \multicolumn{2}{|c|}{$\begin{array}{c}\text { Demodex- } \\
\text { Positive }(n=42)\end{array}$} & \multicolumn{2}{|c|}{$\begin{array}{c}\text { Total } \\
(n=71)\end{array}$} & \multirow{2}{*}{$\mathbf{p}$} \\
\hline & $\mathbf{n}$ & $\%$ & $\mathbf{n}$ & $\%$ & $\mathbf{n}$ & $\%$ & \\
\hline $\begin{array}{l}\text { Bacterial } \\
\text { growth (-) }\end{array}$ & 8 & 27.6 & 4 & 9.5 & 12 & 16.9 & \multirow{2}{*}{$0.048^{*}$} \\
\hline $\begin{array}{l}\text { Bacterial } \\
\text { growth (+) }\end{array}$ & 21 & 72.4 & 38 & 90.5 & 59 & 83.1 & \\
\hline
\end{tabular}

In the culture samples obtained from the 71 patients with chronic blepharitis, aerobic bacterial growth was detected in $59(83.1 \%)$ patients and no bacterial growth was detected in $12(16.9 \%)$ patients. According to the frequency of the bacterial growth, S. epidermidis (35.2\%), S. aureus (15.5\%), S. epidermidis other coagulase-negative Staphylococcus (CNS) (15.5\%), Corynebacterium spp. (12.7\%), and Streptococcus spp. (5.6\%) were identified.

Regarding the distribution of bacterial species, $S$. epidermidis (38.1\% vs. $31.0 \%)$, S. aureus $(19.0 \%$ vs.10.3\%), and Corynebacterium spp.(16.7\% vs. $6.9 \%)$ were observed at higher rates in the Demodex-positive group than in the Demodex-negative group. Streptococcus spp. (6.9\% vs. $4.8 \%)$ and other CNS (20.7\% vs.11.9\%) were detected at higher rates in the Demodex-negative group than in the Demodexpositive group. However, there was no statistically significant difference between the patient groups withrespect to the bacterial species( $p>0.05$ ) (Table 3 ).

Table 3. Comparisons between Demodex-positive and -negative groups with respect to bacterial species

\begin{tabular}{|c|c|c|c|c|c|c|c|}
\hline & \multicolumn{2}{|c|}{$\begin{array}{l}\text { Demodex- } \\
\text { Negative } \\
(n=29)\end{array}$} & \multicolumn{2}{|c|}{$\begin{array}{l}\text { Demodex- } \\
\text { Positive } \\
(n=42)\end{array}$} & \multicolumn{2}{|c|}{$\begin{array}{c}\text { Total } \\
(n=71)\end{array}$} & \multirow[t]{2}{*}{ p } \\
\hline & $\mathbf{n}$ & $\%$ & $\mathbf{n}$ & $\%$ & $\mathbf{n}$ & $\%$ & \\
\hline S. epidermidis & 9 & 31.0 & 16 & 38.1 & 25 & 35.2 & $0.618^{*}$ \\
\hline S. aureus & 3 & 10.3 & 8 & 19.0 & 11 & 15.5 & $0.506^{*}$ \\
\hline Corynebacterium spp. & 2 & 6.9 & 7 & 16.7 & 9 & 12.7 & $0.239 *$ \\
\hline Streptococcus spp. & 2 & 6.9 & 2 & 4.8 & 4 & 5.6 & $1.000 *$ \\
\hline Other CNS & 6 & 20.7 & 5 & 11.9 & 11 & 15.5 & $0.338^{*}$ \\
\hline
\end{tabular}

\section{DISCUSSION}

Blepharitis is a clinical condition frequently observed in the community and generally has a chronic course. Despite the presence of inflammation in the eyelash roots, the aetiology of blepharitis is still not completely understood ${ }^{\left[{ }^{[6]}\right.}$ It is believed that bacterial infections and inflammatory skin lesions such as atopic dermatitis together with $D$. folliculorum infestations play a role in the etiopathogenesis. ${ }^{[11]}$

The results of several studies support the relationship between Demodex and blepharitis. ${ }^{[12-18]}$ In a study conducted by Lee et al. ${ }^{[13]}$ to determine the prevalence of Demodex, positivity was determined at $70 \%$, and a strong correlation was reported between the number of Demodex and the severity of the ocular disorder. In a case-controlled study, Biernat et al. ${ }^{[14]}$ reported Demodex frequencies of $62.4 \%$ in patients with chronic blepharitis and $24.3 \%$ in the control group, with the difference being statistically significant. In another meta-analysis, the probability of developing symptomatic blepharitis was reported to be 4.7 -fold greater in patients with Demodex in the eyelashes. ${ }^{[15]}$ Consistent with these findings in the literature, our study determined a Demodex positivity of $59.1 \%$ in 42 of 71 patients with chronic blepharitis. 
Although previous studies did not find a significant difference in the frequency of $D$. folliculorum according to gender, it has been found to increase with age. ${ }^{[13,14,19]}$ Arici et al. ${ }^{[20]}$ reported that the presence of Demodex was not related to age and gender. Demirmizrak et al. ${ }^{[21]}$ found that there was a statistically significant increase in male gender and the frequency of $D$. folliculorum with increasing age. In the current study as well, although there was no change in the frequency of $D$. folliculorum according to gender, a positive correlation was found between the frequency of Demodex and age.

The eyelid margin is known to host normal bacterial flora consisting of S. epidermidis, S. aureus, and, to a lesser degree, Corynebacterium spp. (22). In a study conducted by Groden et al. ${ }^{[8]}$ the commonly isolated bacteria in patients with chronic blepharitis were S. epidermidis (95.8\%), Corynebacterium spp. (76.8\%), Acinetobacter spp. (11.4\%), and S. aureus (10.5\%). Compared with the control group, the detection rates of $S$. epidermidis and Corynebacterium spp. were significantly higher in patients with chronic blepharitis. Demler et al. ${ }^{[23]}$ reported a $52 \%$ D. folliculorum positivity rate in patients with chronic blepharitis and an increase in both Gram-negative and Grampositive bacteria in the Demodex-positive patients. In a recent study conducted by Zhu et al. ${ }^{[24]} D$. folliculorum frequency $(76.7 \%)$ was found to be significantly higher in patients with chronic blepharitis than in the control group (41.3\%). Moreover, the authors found no statistically significant increase in the density of the aerobic bacteria S. epidermidis and S. aureus in the presence of Demodex mites in the culture samples obtained from the eyelid margin and eyelashes. In the present study, $S$. epidermidis, other CNS, S. aureus, Corynebacterium spp., and Streptococcus spp. were detected in patients with chronic blepharitis. Although bacterial growth was significantly higher in Demodex-positive patients, no significant difference was observed between the bacterial strains. The most frequently isolated bacterium in patients with blepharitis patients has been reported to be S. epidermidis. ${ }^{[7,23]}$ Consistent with this finding in the literature, there was a predominance of $S$. epidermidis in patients with chronic blepharitis in the present study.

Mites function as vectors, especially for Staphylococcus species (25). In the current study, S. epidermidis (38.1\% vs. $31.0 \%)$, S. aureus $(19.0 \%$ vs.10.3\%), and Corynebacterium spp.(16.7\% vs. 6.9\%) were determined at higher rates in Demodex-positive patients than in Demodex-negative patients, but the difference was not statistically significant. This suggests that these bacteria, which are frequently found in the normal eyelid flora, settle more in the eyelash follicles through the mediation of Demodex mites and lead to the formation of a mixed infection. Staphylococci are found in the normal eyelid flora and just like mites, there is an increase in colonisation with age. The biofilm layer formed by S. epidermidis in particular provides a suitable living and nutritional environment for Demodex mites. If the cylindrical layer that forms with the accumulation of the biofilm layer around the eyelash is accepted as a pathognomic finding for Demodex mites, there may be an association between $S$. epidermidis and Demodex mites. ${ }^{[22,26]}$
D. folliculorum causes direct damage to the follicular epithelium within the eyelash follicles in the eyelid and eyelid margin. The development of blepharitis due to the bacteria carried on the surface of Demodex mites triggers the host immune response. The resulting mechanical blockage and the delayed oversensitivity reaction cause inflammation in the eyelid margin..$^{[1]}$ In a study conducted by Kim et al. ${ }^{[27]}$ the levels of IL-17, causing inflammation of the eyelid and ocular surface, weredetected at a significantly higher rate in patients with Demodex-infected blepharitis, indicating inflammatory events (27).

Due to the uncertainty in etiopathogenesis, the treatment for blepharitis is confusing and ineffective, and the majority of cases become chronic. In blepharitis cases, bacterial infections and allergies are considered initially, due to which antibacterial and steroid drops are generally used in empirical treatment. If the cause of blepharitis is $D$. folliculorum infestation, the patient would not benefit from this treatment and the condition could become chronic. Pretreatment detection of the parasite may be beneficial, especially in treatment-resistant chronic blepharitis patients. ${ }^{[28]}$ As found in the present study, D. folliculorum and bacterial agents are often detected together in patients with chronic blepharitis and it must be remembered that this creates a complicated infection site, which must not be ignored in the treatment process. Therefore, the use of tea tree oil is predominant in the treatment as it has been proven to have antiparasitic, antibacterial and anti-inflammatory effects in previous studies. ${ }^{[2,30]}$ In invivo and invitro studies conducted by Goa et al. $^{\left[{ }^{[31]}\right.}$ it was observed that Demodex mites were effectively eliminated by treatment with tea tree oil.

A limitation of the present study was that the patients were not followed up after treatment. In future studies, changes in the combination of bacterial strains and $D$. folliculorum should be investigated after the application of various treatments, which would helpin determining the treatment efficacy in more detail.

\section{CONCLUSION}

The results of this study suggest that in patients with chronic blepharitis, a mixed infection area is formed by the combination of $D$. folliculorum and aerobic bacteria found in the normal eyelid flora. It is beneficial to consider these results during the initiation ofempirical treatment in patients with chronic blepharitis.

\section{ETHICAL DECLARATIONS}

Ethics Committee Approval: This study was approved by the Clinical Research Ethics Committee of Karabük University Medical Faculty (no: 13, dated:31/08/2016)

Informed Consent: All patients signed the free and informed consent form.

Referee Evaluation Process: Externally peer-reviewed. 
Conflict of Interest Statement: The authors have no conflicts of interest to declare.

Financial Disclosure: This study was supported by Afyonkarahisar health sciences university medical faculties Fund (Project Number: 2020/396).

Author Contributions: All of the authors declare that they have all participated in the design, execution, and analysis of the paper, and that they have approved the final version.

\section{REFERENCES}

1. Liu J, Sheha H, Tseng SC. Pathogenic role of Demodex mites in blepharitis. Curr.Opin. Allergy Clin. Immunol. 2010; 10:505-510.

2. Nutting WB, Green AC. Hair follicle mites (Acari: Demodicidae) from Australian aborigines. Aust. J. Dermatol.1974; 15:10-14.

3. Kheirkhah A, Casas V, Li W, Raju VK, Tseng SC. Corneal manifestations of ocular demodex infestation. Am. J.Ophthalmol. 2007; 143:743-749.

4. Luo X, Li J, Chen C, Tseng S, Liang L. Ocular demodicosis as a potential cause of ocular surface inflammation. Cornea. 2017; 36:9-14.

5. Bhandari V, Reddy JK. Blepharitis: always remember demodex. Middle East Afr. J.Ophthalmol. 2014; 21:317-320.

6. Kanski JJ, Bowling B. Clinical ophthalmology: A systematic approach. Elsevier Health Sciences. 2011.

7. Baima B, Sticherling M. Demodicidosis revisited. Acta Derm.Venereol. 2002; 82:3-6.

8. Groden LR, Murphy B, Rodnite J, Genvert GI. Lid flora in blepharitis. Cornea, 1991; 10:50-53.

9. Kamoun B, Fourati $M$, Feki J, Mlik M, Karray F, Trigui A et al. Blépharite à Démodex: mytheouréalité. J. Fr.Ophtalmol. 1999; 22:525-527.

10. English FP, Nutting WB, Cohn D. Eyelid mite nests. Aust 3 Ophthaimol. 1982; 10:187-189.

11. Lindsley K, Matsumura S, Hatef E, Akpek EK. Interventions for chronic blepharitis. Cochrane Database Syst. Rev.2012; 5, CD005556. doi: 10.1002/14651858.CD005556.pub2

12. Rusiecka-Ziólkowska J, Nokiel M, Fleischer M. Demodex - An old pathogen or a new one? Adv. Clin. Exp. Med. 2014; 23:295-298.

13. Lee SH, Chun YS, Kim JH, Kim ES, Kim JC. The relationship between Demodex and ocular discomfort. Investig. Ophthalmol. Vis. Sci.2010; 51: 2906-2911.

14. Biernat MM, Rusiecka-Ziółkowska J, Piątkowska E, Helemejko I, Biernat $P$, Gościniak G. Occurrence of Demodex species in patients with blepharitis and in healthy individuals: a 10-year observational study. Jpn. J. Ophthalmol. 2018; 62, 628-633.

15. Zhao YE, Wu LP, Hu L Xu JR. Association of blepharitis with Demodex: a meta-analysis. Ophthalmic Epidemiol. 2012; 19:95-102.

16. Eroglu S, Cakmakliogullari M, KalCakmakliogullari E. Is the presence of Demodex folliculorumincreased with impaired glucose regulation in polycystic ovary syndrome?J. Obstet. Gynaecol.2019; 1-5.

17. Gonzalez-Hinojosa D, Jaime-Villalonga A, Aguilar-Montes G, LammogliaOrdiales L. Demodex and rosacea: Is there a relationship? Indian J. Ophthalmol.2018; 66:36.

18. Patel NV, Mathur U, Gandhi A, \& Singh M. Demodex blepharokeratoconjunctivitis affecting young patients: A case series. Indian J. Ophthalmol. 2020; 68:745.

19. Wesolowska M, Knysz B, Reich A, Blazejewska D, Czarnecki M, Gladysz A et al. Prevalence of Demodex spp. in eyelash follicles in different populations. Arch. Med. Sci. 2014; 10:319-324.

20. Arıcı KM, Sumer Z, Toker Ml, Erdogan H, Topalkara A, Akbulut M. The prevalence of Demodex folliculorumin blepharitis patients and the normal population. Ophthalmic. Epidemiol. 2005; 12: 287-290.

21. Demirkazık M, Koltaş is. Demodex Kaynaklı Blefarit Olguları. Turkiye Parazitol Derg 2020; 44:21-24.

22. Rynerson JM, Perry HD. DEBS-a unification theory for dry eye and blepharitis. Clin. Ophthalmol.(Auckland, NZ) 2016; 10:2455.

23. Demmler M, Möhring C, Klauss V. Blepharitis. Demodex folliculorum, associated pathogen spectrum and specific therapy. Ophthalmologe. 1997; 94:191-196
24. Zhu M, Cheng C, Yi H, Lin L, Wu K. Quantitative analysis of the bacteria in blepharitis with demodex infestation. Front. Microbiol. 2018; 9:1719

25. Shelley WB, Shelley ED, Burmeister V. Unilateral demodectic rosacea. J. Am. Acad. Dermatol.1989; 20:915-917.

26. Gao YY, Di Pascuale MA, Li W, Liu DT, Baradaran-Rafii A, Elizondo A, et al. High prevalence of Demodex in eyelashes with cylindrical dandruff. Investig. Ophthalmol. Vis. Sci. 2005; 46:3089-3094.

27. Kim JT, Lee SH, Chun YS, Kim JC. Tear cytokines and chemokines in patients with Demodex blepharitis. Cytokine. 2011; 53:94-99.

28. Tanrıverdi C, Demirci G, Balcı Ö, Odabaşı M, Özsütçü M. Investigation of Demodex Parasitic Existence in Treatment-Resistant Chronic Blepharitis Cases. Turkiye Parazitol Derg 2018; 42: 130-3.

29. Messager S, Hammer KA, Carson CF, Riley TV. Assessment of the antibacterial activity of tea tree oil using the European EN 1276 and EN 12054 standard suspension tests. J. Hosp. Infect. 2005; 59:113-125.

30. Halcón L, MilkusK.Staphylococcus aureus and wounds: a review of tea tree oil as a promising antimicrobial. Am. J. Infect. Control2004; 32:402-408.

31. Gao YY, Di Pascuale MA, Li W, Baradaran-Rafii A, Elizondo A, Kuo CL et al. In vitro and in vivo killing of ocular Demodex by tea tree oil. Br. J.Ophthalmol. 2005; 89:1468-1473. 